\title{
Impact of Nuclear Accidents In Public Health
}

Deepa Singh

BPH $23^{\text {rd }}$ Batch
Nuclear Accidents can be defined as an unexpected event involving nuclear weapons or radiological nuclear weapon components that results in any of the following;
a. Accidental or unauthorized launching, firing,
b. Nuclear detonation
c. Non nuclear detonation or burning of a nuclear weapon or radiological nuclear component
d. Radioactive contamination
e. Seizure, theft, loss or destruction of a nuclear weapon or radiological nuclear weapon
f. Public hazard.

\section{Nuclear accidents; impact in public health}

Apart from the damage caused by fires and explosions, accidents also release radioactive materials which can cause radiation sickness. Radiation exposure above a certain threshold, usually only received by workers and emergency teams in a stricken plant, causes acute radiation syndrome within hours of exposure. Depending on the dose of radiation this ranges from skin rashes, vomiting and diarrhoea, to coma and death.

Radiation damages DNA, especially as it assembles in dividing cells. That means tissues which contain many dividing cells, such as the gut lining, skin and bone marrow, are most at risk of damage. High enough doses also damage brain cells and such doses are invariably fatal.

Less severe damage can be treated, however. Gut damage disturbs fluid balance and can lead to blood infection; marrow damage means no blood cells are produced for clotting and fighting infection. If those problems can be managed, people can be kept alive long enough for gut and marrow to regenerate. A cloned human hormone that boosts white blood cell production sometimes helps; there is little else.

\section{Dangers of radiation}

When unstable atoms naturally break down (decay) they release they release radioactive particles. There are three types of particles: alpha á,beta â and gamma ã. They are considered dangerous as they are able to ionise. They are able to change the structure of atoms by knocking off or dragging electrons away from the atom.

In humans, animals and plants, this ionising effect alters the DNA code in cells causing cell mutation. Through this, the altered cells are reproduced through cell division which may then form cancerous growths. The corrupted code can also contribute to mutated limbs, organ functionality and death.

This radiation isn't only sourced from the site of a nuclear disaster. Poising can occur through contaminated water which then infects soil and hence food supplies. To add more to this potential problem, radioactive particles can stay hazardous for thousands of years.

Because of this danger, workers at nuclear power plants are specially trained and adhere to strict safety precautions. Additionally, power plants usually have emergency shutdown procedures which automatically initiate when problems arise.

Fears of nuclear terrorism have recently inspired more funding for research into new treatments, most aiming to limit cell death in damaged tissues.

\section{TOP 5 WORST NUCLEAR DISASTERS IN HUMAN HISTORY}

\section{Chernobyl, Soviet Union (now Ukraine) April 26, 1986}

The Chernobyl nuclear accident is widely regarded as the worst accident in the history of nuclear power. It is the only nuclear accident that has been classified a "major accident" by the International Atomic Energy Agency (IAEA).

Kyshtym, Soviet Union (now Russia) Sept. 29, 1957

The Soviet Union was also home to the second-most disastrous nuclear accident, at the Mayak Nuclear Power Plant near the city of Kyshtym. IAEA classified the event as a Level 6 Disaster, which is a "serious accident."

\section{Windscale Fire, Great Britain Oct. 10, 1957}

Great Britain's first foray into nuclear energy had been successful for several years before the Windscale fire occurred in 1957. Operators noticed that the reactor's temperature was steadily rising when it should have been decreasing. They originally suspected the equipment was malfunctioning, so two plant workers went to inspect the reactor. When they reached the reactor, they discovered it was engulfed in flames.

Three Mile Island, United States March 28, 1979

The United States' most disastrous nuclear accident took place at the Three Mile Island Plant near Harrisburg, Penn., the state's capitol. 
Fukushima Daiichi, Japan 11 March 2011

The crisis at the Fukushima Daiichi nuclear power plant is the worst nuclear accident since Chernobyl in Ukraine in 1986. However, so far it seems more likely to resemble the Three Mile Island (TMI) accident in Pennsylvania in 1979 which, like Fukushima, lost coolant and had a partial meltdown. The Japanese authorities have announced that radiation levels surrounding the Fukushima Daiichi nuclear power plant are increasing to potentially harmful levels. New Scientist investigates the health risks associated with nuclear power plant explosions

\section{References}

1. European Nuclear Society. (2011, January 20). Nuclear power plants, world-wide. Retrieved from <http:// www.euronuclear.org/info/encyclopedia/n/nuclearpower-plant-world-wide.htm>

2. World Health Organization, Initials. (April 2006). Health effects of the Chernobyl accident: an overview. (2006). WHO media center. 